\title{
Long-term survival of endothelium following transplantation of corneas stored by organ culture
}

\author{
R M Redmond, W J Armitage, J Whittle, S J Moss, D L Easty
}

\begin{abstract}
This study reports corneal graft survival, endothelial cell changes, and visual outcome in 20 patients who received some of the first corneas stored by organ culture in the Corneal Transplant Service Eye Bank in Bristol. Mean donor age was 48 years (SD $15, n=20)$ and corneas were stored for an average of 21 days (SD 7, $n=20$ ). Preoperative endothelial cell density was 2334 cells $/ \mathrm{mm}^{2}(\mathrm{SD} 235, n=18)$ and this fell by $8 \%$ (SD 12) to 2158 cells $/ \mathrm{mm}^{2}$ (SD 372) within the first 2 months following transplantation. In 13 patients, endothelial cell density thereafter declined exponentially with a half-life of 41 months (SD 17, $n=12$; one patient excluded as an outlier). Corneas that suffered rejection episodes showed the highest rates of loss of endothelial cells. Endothelial cell loss 4 years after transplantation was $46 \%$ (SD 16, $n=12$, which was similar to the postoperative decline in cell density reported for corneas stored for far shorter periods in McCarey-Kaufman medium at $4^{\circ} \mathrm{C}$.

(Brf Ophthalmol 1992; 76: 479-481)
\end{abstract}

The Corneal Transplant Service (CTS) Eye Bank was set up in Bristol in 1986 to help meet the increasing demand for corneal tissue in the UK..$^{12}$ Organ culture at $34^{\circ} \mathrm{C}$ was chosen as the principal storage method because it offered significant advantages. ${ }^{3-5}$ Organ culture allows corneas to be stored for more than 4 weeks, facilitating elective transplantation, reducing tissue wastage and improving the distribution of corneas from tissue-typed donors. Bacterial or fungal contamination of donor tissue is minimised by cleaning eyes before excision of corneoscleral discs and by the addition of antibiotics and antimycotics to the culture medium. Finally, Coster $^{6}$ has speculated that organcultured corneas might be less antigenic than corneas stored at $4^{\circ} \mathrm{C}$.

Since 1986, more than 6500 corneas stored in the CTS Eye Bank have been supplied to hospitals throughout the UK. Although shortterm outcome of organ-cultured grafts has been reported,$^{78}$ Galloway ${ }^{9}$ has referred to the lack of long-term follow-up. The aim of the present study was to follow the long-term endothelial changes in corneal grafts in patients who received some of the first corneas stored by organ culture in the CTS Eye Bank.

\section{Methods}

\section{Patients}

Twenty patients who had undergone penetrating keratoplasty in Bristol Eye Hospital using corneal tissue stored by organ culture were followed for up to 4 years. One patient died in the first year and was lost to follow-up. Mean patient age was 56 years (SD 20, $n=20$ ) and there was a preponderance of females to males of 13:7. There were five cases of Fuchs' endothelial dystrophy, three cases of herpes simplex keratitis, three regrafts (original diagnoses were herpes simplex keratitis and, in two cases, keratoconus), three cases of bullous keratopathy, two cases of keratoconus, two cases of lattice dystrophy, and two cases of interstitial keratitis.

Corneal grafts were performed according to a standard procedure at Bristol Eye Hospital. Donor buttons were punched from the endothelial side using Pharmacia disposable trephines that were $0.25 \mathrm{~mm}$ larger than those used for the recipient. A double continuous suture was used and the knots were buried at the interface. Particular care was taken to ensure a watertight interface.

\section{Donor corneas}

Mean donor age was 48 years (SD 15, $n=20$ ) and the corneas were stored for an average of 21 days (SD 7). Corneas were stored at $34^{\circ} \mathrm{C}$ in Eagle's minimum essential medium containing hepes buffer, fetal calf serum (2\%), sodium bicarbonate (24 mmol/l), L-glutamine $(2 \mathrm{mmol} / \mathrm{l})$, penicillin (100 units $/ \mathrm{ml})$, streptomycin $(0 \cdot 1 \mathrm{mg} / \mathrm{ml})$, and amphotericin B $(0.25 \mu \mathrm{g} / \mathrm{ml}){ }^{5}$ Two days before transplantation, corneas were removed from the culture medium and the endothelium was examined using a light microscope following staining with trypan blue and sucrose. This allowed corneas with fewer than 2000 endothelial cells $/ \mathrm{mm}^{2}$ or with endothelial defects to be excluded. The endothelium was also photographed to permit a more accurate determination of preoperative cell density. Corneas were then placed into medium containing 5\% dextran and returned to $34^{\circ} \mathrm{C}$ for a further 2 days to thin them prior to transplantation.

\section{Postoperative endothelial cell density}

Patients were examined with a wide-field specular microscope (Keeler-Pocklington) at 2, 6 , and 12 months following transplantation and then at yearly intervals. Follow-up was not available for every patient at all follow-up times. Scanning of the posterior corneal surface concentrated on the central 4-mm region and did not follow a rigid grid pattern. ${ }^{10}$ Pachymetry was performed using the Pocklington microscope during the first postoperative year and intraocular pressure was monitored using Goldmann applanation tonometry throughout the 4-year follow-up period. 
Endothelial morphometric analysis was carried out using 35-mm negatives and a Kontron-MOP system. A $0.01 \mathrm{~mm}^{2}$ grid in the film plane of the specular microscope ensured that each $35-\mathrm{mm}$ negative could be scaled accurately. Measurements of cell perimeter, cell surface area, maximum diameter, and shape factor were made on up to 50 individual cells from each cornea. Cell clusters were avoided and cells were selected at random from 5-6 negatives. Cell density was calculated from the reciprocal of cell area. Thus, up to 50 estimates of cell density were obtained for each patient at any given postoperative assessment time.

Changes in endothelial cell density with time were studied in individual patients. An exponential equation of the form $D=D_{0} e^{-k t}$, where $D$ is cell density $\left(\right.$ cells $\left./ \mathrm{mm}^{2}\right), D_{0}$ is initial cell density, $k$ is an exponential rate constant and $t$ is time after transplantation (months), was fitted to the data from each patient by least squares regression, ensuring equal numbers of estimates of cell density at each follow-up time. The time taken for cell density to fall by $50 \%$ (the half-life) was calculated for each patient, where appropriate, from $0 \cdot 693 / k$.

\section{Results}

\section{Clinical outcome}

Immediately following transplantation, organcultured corneas were thicker and more opalescent than corneas that had been stored at $4^{\circ} \mathrm{C}$. The inflammatory response of the anterior segment was low, but grafts cleared relatively slowly, taking 3-4 weeks to achieve good transparency. Six months after transplantation, mean corneal thickness was $0.53 \mathrm{~mm}(\mathrm{SD} 0.06, n=9)$ and intraocular pressure was $17 \cdot 2 \mathrm{~mm} \mathrm{Hg}$ (SD $6 \cdot 0, n=9)$.

Fine folds in Descemet's membrane were universal and persisted adjacent to the graft-host interface. These folds did not-impair vision because the central area was quite clear after the first month. The improvement in visual acuity, excluding those cases where retrocorneal pathology precluded good macular function, is shown in Figure 1. Astigmatism at 1 year ranged from $0-9$ dioptres with a mean value of $4 \cdot 1$ (SD $2 \cdot 7, n=13$ ).

\section{Endothelial changes}

Preoperative cell density of the donor corneas was 2334 cells $/ \mathrm{mm}^{2}$ (SD 235, $n=18$ - data not

Figure 1 Change in visual acuity following transplantation.

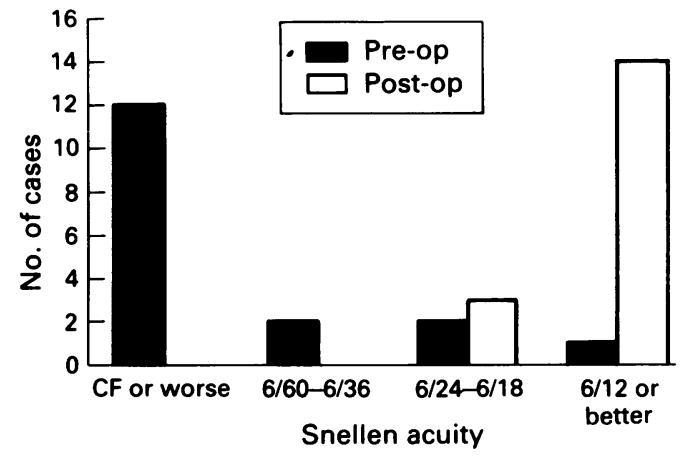

available for two corneas). Two months after transplantation, endothelial cell density in this same group of patients had declined to 2158 cells/ $\mathrm{mm}^{2}$ (SD 372, $n=18: p<0.01, c f$ pre-op density, paired $t$ test). This represented an average loss of $8 \%(95 \%$ CI $2-14 \%, n=18)$. Follow-up data for 4 years was available for 12 patients (Table 1). Four years after transplantation, these corneas had lost $46 \%$ (95\% CI 35-56\%, $n=12$ ) of their cells compared with the preoperative cell density. The cell loss compared with the 2-month postoperative cell density was $42 \%$ (95\% CI $30-53 \%$, $n=12$ ).

After the initial fall during the first 2 postoperative months, endothelial cell density continued to decline exponentially in 13 of the transplanted corneas. The other seven corneal grafts showed inconsistent patterns of change in cell density - there were no overt reasons for this difference (Table 2). Because exponential rates of cell loss varied significantly between patients $(p<0.001)$, the data were not pooled to calculate a single regression equation; however, the mean half-life for the decline in cell density was 41 months (SD 17, $n=12$ ). One cornea with a halflife of 407 months was excluded as an outlier ( $<<0.01$, Dixon test). Two corneas that suffered rejection episodes and subsequently failed after 3 years had the shortest half-lives (that is, the highest rates of cell loss), namely 14.7 and 21.5 months. Of the 12 corneas with 4-year follow-up, seven (excluding the outlier) showed an exponential decline in cell density with an average half-live of 47 months (SD 16, $n=7$ ).

\section{Discussion}

Bourne $e t a l^{7}$ suggested that survival of donor endothelial cells following transplantation is a

Table 1 Change in mean endothelial cell density of corneal grafts in 12 patients followed for 4 years

\begin{tabular}{ll}
\hline & Cells/mm:(SD) \\
\hline $\begin{array}{ll}\text { Preoperative cell density } \\
\text { Postoperative cell density: }\end{array}$ & $2379(242)$ \\
2 months & $2233(380)$ \\
48 months & $1292(375)$ \\
\hline
\end{tabular}

Table 2 Comparison between the group that showed an exponential postoperative decline in endothelial cell density and the group that showed no consistent pattern of change

\begin{tabular}{|c|c|c|}
\hline & $\begin{array}{l}\text { Exponential } \\
(\mathrm{n}=13)\end{array}$ & $\begin{array}{l}\text { Inconsistent } \\
(\mathrm{n}=7)\end{array}$ \\
\hline \multicolumn{3}{|l|}{ Patient: } \\
\hline \multicolumn{3}{|l|}{ Diagnosis: } \\
\hline Fuchs' dystrophy & 4 & 1 \\
\hline Regraft & 2 & 1 \\
\hline Keratoconus & 2 & - \\
\hline Herpes keratitis & 1 & 2 \\
\hline Lattice dystrophy & 2 & - \\
\hline Interstitial keratitis & 1 & 1 \\
\hline Bullous keratopathy & $i$ & 2 \\
\hline \multicolumn{3}{|l|}{ Donor cornea: } \\
\hline $\begin{array}{l}\text { Donor age (years) } \\
\text { Storage time (days) }\end{array}$ & $\begin{array}{l}49(\text { SD 14) } \\
21(\text { SD } 8)\end{array}$ & $\begin{array}{l}46(\text { SD 18) } \\
22(\text { SD 7) }\end{array}$ \\
\hline Pre-op cells $/ \mathrm{mm}^{2}$ & $\underset{(n=11)^{\star}}{2320(S D)}$ & 2357 (SD 311) \\
\hline 2-month cell/mm² & $\begin{array}{l}2147(\text { SD } 226) \\
(n=11)\end{array}$ & 2175 (SD 554) \\
\hline 2-month cell loss (\%) & $\begin{array}{l}7 \text { (SD 8) } \\
(n=11)\end{array}$ & $8(S D 16)$ \\
\hline
\end{tabular}


more sensitive indicator of the efficacy of corneal preservation techniques than clinical outcome because corneas can remain transparent with as few as 500 cells $/ \mathrm{mm}^{2} .{ }^{11}$ Bourne and his colleagues have reported long-term changes in transplanted corneas following storage in McCarey-Kaufman $(\mathrm{M}-\mathrm{K})$ medium at $4^{\circ} \mathrm{C}^{7}$ and short-term changes in corneas stored in organ culture at $34^{\circ} \mathrm{C} .1213$ Their data thus form a baseline for comparison with the changes observed in the present study.

Preoperative cell densities were higher in Bourne's studies, ${ }^{781213}$ ranging from approximately $2800-3300$ cells $/ \mathrm{mm}^{2}$, than the 2334 cells/ $\mathrm{mm}^{2}$ (95\% CI 2217-2451, $\left.n=18\right)$ of the present study. However, the initial loss of cells during the first 2 months following transplantation in the two long-term studies of corneas that had been stored in $\mathrm{M}-\mathrm{K}$ medium ${ }^{1213}$ was far higher $(>30 \%)$ than the $8 \%(95 \%$ CI $2-14 \%, n=18)$ seen in the Bristol patients. Thereafter, the loss of cells betwen 2 and 48 months of approximately $45 \%$ reported by Bourne ${ }^{12}$ and by Matsuda and Bourne ${ }^{13}$ was similar to this study - namely, $42 \%$ (95\% CI 30-53\%, $n=12$ ).

Although based on mean cell densities calculated from pooled data rather than on the changes observed in individual patients, Bourne $^{7}$ also found an exponential decline in cell density, but only over the first 3 years after transplantation. The slope of his regression equation gives a half-life of 2.9 years, which is similar to the 3.4 years $(95 \%$ CI $2 \cdot 5-4 \cdot 3$ years, $n=12)$ observed in the Bristol patients.

In another study, the efficacy of organ culture was rightly called into question by Bourne $e t a l^{12}$ who reported higher rates of endothelial cell loss over the first 2 postoperative months from organ cultured corneas $(28 \%, \mathrm{SD} 17, n=75)$ than from corneas stored in $\mathrm{M}-\mathrm{K}$ medium (9\%, SD 17, $n=75)$. One year after transplantation, the cell density of corneas stored in $\mathrm{M}-\mathrm{K}$ medium was 2121 cells $/ \mathrm{mm}^{2}$ (SD 680, $n=47$ ) compared with 1704 cells $/ \mathrm{mm}^{2}$ (SD 702, $n=47$ ) in organ cultured grafts, representing cell losses of $25 \%$ (SD 24, $n=47$ ) and $44 \%$ (SD 19, $n=47$ ), respectively. The initial cell loss from corneas stored in M-K medium was much lower than in Bourne's earlier series $^{1213}$ and is similar to the loss seen in the present series of organ-cultured grafts. Furthermore, despite a lower preoperative cell density, the Bristol organ-cultured grafts had a 1 year cell density of 1946 cells $/ \mathrm{mm}^{2}$ (95\% CI 1537-2356, $n=12$ ).

Bourne $e t \mathrm{al}^{7}$ showed that transferring corneas from organ culture to $\mathrm{M}-\mathrm{K}$ medium at $4^{\circ} \mathrm{C}$ for several hours before transplantation, presumably to thin the corneas, was deleterious. They pointed out that the temperature change from $34^{\circ}$ to $4^{\circ} \mathrm{C}$ might compromise the ability of the endothelium to survive the trauma of transplantation. Corneas that were organ cultured but not transferred to $\mathrm{M}-\mathrm{K}$ medium at $4^{\circ} \mathrm{C}$ had lower rates of cell loss, although the rates were still higher than in corneas stored only in $M-K$ medium. The organ culture technique used in
Bristol was orginally developed in Århus and Amsterdam and differs from that used formerly in Minneapolis. Two days before transplantation, the corneal endothelium is examined and, if judged to be suitable, the cornea is placed into medium containing $5 \%$ dextran, but the cornea is not refrigerated. This allows the cornea to dehydrate and thin prior to transplantation. The corneas transplanted by Bourne et $a l^{12}$ were either refrigerated or were thickened at the time of transplantation. The inclusion of $1.35 \%$ chondroitin sulphate in the organ culture medium eliminated the difference in cell loss between organ culture and $M-K$ storage observed by Bourne $e t a l^{78}$ which, taken together with the present study, suggests that intermediateterm organ culture can be as effective as shortterm $4^{\circ} \mathrm{C}$ storage at preserving the endothelium.

In summary, this study of patients grafted in Bristol suggests that the rate of postoperative endothelial cell loss from organ cultured corneas is no worse than the loss expected from corneas stored for much shorter periods at $4^{\circ} \mathrm{C}$, thus confirming the efficacy of intermediate-term corneal storage by organ culture. In the early postoperative period, eyes that received organcultured corneal grafts were judged to be 'quiet', and problems with severe anterior uveitis were not encountered. This may have been related to the elimination of bacterial or fungal contamination during organ culture or to a putative reduction in antigenicity. ${ }^{6}$

We thank Professor B A Bradley, UK. Transplant Support Service (UKTSS), for his continuing support of the CTS Eye Bank. Dr C Rogers and Andy Vail, biostatisticians at UKTSS, provided invaluable statistical support and advice. We are grateful for financial support from the Iris Fund for the Prevention of Blindness, the Halley Stuart Trust, the British Council for the Prevention of Blindness, and the National Eye Research Centre. Special thanks are also due to Dr W M Bourne for providing some raw data from an earlier study (Matsuda and Bourne, 1985) to allow more detailed comparisons.

1 Bradley BA. Corneal supply in the United Kingdom. Trans Ophthalmol Soc UK 1986; 105:397-400.

2 Armitage WJ, Moss SJ, Easty DL, Bradley BA. Supply of corneal tissue in the United Kingdom. Br f Ophthalmol 1990 74: 685-7

3 Doughman DJ, Harris JE, Schmitt MK. Penetrating keratoplasty using $37^{\circ} \mathrm{C}$ organ cultured cornea. Ophthalmology

4 Pels E, Schuchard Y. Organ-culture preservation of human corneas. Doc Ophthalmol 1983; 56: 147-53.

5 Armitage WJ, Moss SJ. Storage of corneas for transplantation. In: Easty DL, ed. Current ophthalmic surgery. London: In: Easty DL, ed. Corre Tindall, 1990.

6 Coster DJ. Mechanisms of corneal graft failure: the erosion of corneal privilege. Eye 1989; 2: 251-62.

7 Bourne WM, Doughman DJ, Lindstrom RL. Decreased endothelial cell survival after tranplantation of corneas preserved by three modifications of corneal organ culture technique. Ophthalmology 1985; 92: 1538-41.

8 Bourne WM, Lindstrom RL, Doughman DJ. Endothelial cell survival on transplanted human corneas preserved by organ culture with $1.35 \%$ chondroitin sulfate. Am $\mathcal{F}$ Ophthalmol 1985; 100: 789-93.

9 Galloway NR. [Editorial.] Eye 1990; 4(1): ix.

10 Bourne WM, O'Fallon WM. Endothelial cell loss during penetrating keratoplasty. Am f Ophthalmol 1978; 85: 760-6. penetrating keratoplasty. Am f Ophthalmol 1978; 85: 760-6.
Abbot RL, Fine M, Guillet E. Long-term changes in corneal Abbot RL, Fine $M$, Guillet E. Long-term changes in corneal
endothelium following penetrating keratoplasty: a specular endothelium following penetrating keratoplasty: a sp
microscopic study. Ophthalmology 1983; 90: 676-85.

12 Bourne WM. Chronic endothelial cell loss in transplanted corneas. Cornea 1983; 2: 289-94.

13 Matsuda M, Bourne WM. Long-term morphologic changes in the endothelium of transplanted corneas. Arch Ophthalmol 1985; 103: 1343-6. 